\title{
The financial report of the universities: maintaining academic standards? An empirical research to the size with explanation of the differences
}

Citation for published version (APA):

Volmer, F. G. (2001). The financial report of the universities: maintaining academic standards? An empirical research to the size with explanation of the differences. METEOR, Maastricht University School of Business and Economics. METEOR Research Memorandum No. 032 https://doi.org/10.26481/umamet.2001032

Document status and date:

Published: 01/01/2001

DOI:

10.26481/umamet.2001032

Document Version:

Publisher's PDF, also known as Version of record

Please check the document version of this publication:

- A submitted manuscript is the version of the article upon submission and before peer-review. There can be important differences between the submitted version and the official published version of record.

People interested in the research are advised to contact the author for the final version of the publication, or visit the DOI to the publisher's website.

- The final author version and the galley proof are versions of the publication after peer review.

- The final published version features the final layout of the paper including the volume, issue and page numbers.

Link to publication

\footnotetext{
General rights rights.

- You may freely distribute the URL identifying the publication in the public portal. please follow below link for the End User Agreement:

www.umlib.nl/taverne-license

Take down policy

If you believe that this document breaches copyright please contact us at:

repository@maastrichtuniversity.nl

providing details and we will investigate your claim.
}

Copyright and moral rights for the publications made accessible in the public portal are retained by the authors and/or other copyright owners and it is a condition of accessing publications that users recognise and abide by the legal requirements associated with these

- Users may download and print one copy of any publication from the public portal for the purpose of private study or research.

- You may not further distribute the material or use it for any profit-making activity or commercial gain

If the publication is distributed under the terms of Article 25fa of the Dutch Copyright Act, indicated by the "Taverne" license above, 
The Financial Report of the Universities: maintaining academic standards?

An empirical research to the size with explanation of the differences

Dr. F.G. Volmer (Maastricht University)

June 2001

1. Introduction and research questions: the financial impact of the universities and its financial report

2. Rules concerning financial university reports

2.1 the reporting rules in general

2.2 the reporting rules in particular

2.3 the new reporting rules $(2000)$

3. Earlier research

4. Empirical research: descriptive statistics (1998)

5. Hypotheses

6. Disclosure research

7. Conclusions

\section{Abstract}

This paper describes research done concerning the size, level and explanation of the financial reports of 14 Dutch universities.

Based on earlier research in the USA concerning the financial report of universities, 14 Dutch financial reports are examined. See the Tables.

In spite of the regulations the quantity and quality of the financial university reports diverge much, in particular the information provided about costs and output of education and research varies from university to university.

For an explanation of the data a number well-known hypothesis such as Zimmerman's size, debt/equity hypothesis were tested first. After that a disclosure index was developed for expressing the several information items in a unique report mark per university.

The results can be explained by the kind of university, the size (number of students and revenues) and the long-term liabilities, in accordance with the research abroad. Therefore the main conclusion is that the findings of the research outside the Netherlands such as the importance of size and long-term liabilities hold largely in the Netherlands, too. 
The universities have much impact on the local economy. Total costs and revenues of all universities together amounted to nearly 8 billions of guilders in 1998 . The costs for making a graduate vary much per university from 153.000 to 568.000 guilders. Sound financial reporting may be important for insight in the spending efficiency and discussions about the promoting of the efficiency.

Groves, Pendlebury and Stiles (1997) stated:

"The cozy and comfortable world of the ivory tower image of an university is probably gone forever and universities have to learn to exist in a world where completion effects all of their activities".

History

The university of Leiden is the oldest university of the Northern Netherlands. Witkam (1980) described the finance of the university in the sixteenth century including the accounts. He found that at the beginning the finance was very difficult: in September 1513 was it necessary to borrow 1800 pounds at $12 \%$ to pay the salaries of the professors during October.

In 1584 the retributions from Delfland and Rijnland in total amounted to 6600 pounds, gathered by all kinds of levying In 1584, the budget appropriated to the university amounted to 8000 guilders a year. The establishment of a library, the alimentation of the driven away conventual's-dwellers of the university buildings cost a lot of money. Therefore, the curates and mayors wanted to be involved in he audit of the accounts and a resolution of May 20th, 1587 made the former executives relating to the lease of university lands.

In 1591, the States founded the Collegium Theologiae endowed with 8000 guilders a year, financed by the sale of nationalized monasteries.

The Rekenkamer (governmental audit office) played an important role with relation to the financial control in turbulent times: which properties belong to the university and has the university really received the promised money.

Accurate accounting and closing of the accounts or recording rights and promises by the Leiden University were a condition for surviving.

For many years, the Ministry of Education, Culture and Science (OC \& W) strives for a cost model in agreement with the efficiency and effectiveness parameters of the institutions. In the former HOBEK and STABEK models, the number of graduates and enrolled students were included.

In the recent cost performance model (PBM 2000), a distinction is made between the education performance such as number of graduates and research performance such as finished doctoral dissertations. The Maastricht Allocation (UMA 2000) works it out for the internal resources allocation. The performance measurement is in the center of interest and therefore comparative research of the financial reporting of universities turns out to be necessary The Commission Koopmans already found that the comparability of the university financial reporting could be improved. If the worst comes to the worst, the cost models missed a foundation. 


\section{Rules concerning financial university reports}

\section{1 the reporting rules in general (law, audit, responsibility of directors)}

Article 2.9 of the Higher Education and Scientific Research Law regulates the (financial) report of the State-Aided Universities. The report consists of the annual accounts with the related budget, the Director's report and the other information. The report must show how far the subsided tasks are executed and the level of efficiency used in the performance. The financial report renders an account of the financial control of a university over the last fiscal year. The report includes an opinion of an auditor. Article 2.14 provides that the Minister can give a lead concerning budget and report. Two separate financial reporting guidelines were issued: one for the schools (OC \& W 1996, nr. 316), the other for the universities (OC \& W 1995, nr. 31).

Both guidelines were rewritten in August 2000 and integrated in a combined guideline university reporting.

The annual accounts shall, on the basis of generally accepted accounting principles, give a true and fair view of the state of affairs and results of an university and to the extent that the nature of annual accounts permits, of its solvency and liquidity (article 2, 1995 rules)

\section{2 the reporting rules in particular}

Some features of the 1995 reporting rules

Books

In contrary to the Civil Code, books are a part of the tangible fixed assets, unless the amounts are written down immediately (article 7 Guidelines).

\section{Securities}

Investments not being long-term investments should be recorded under short-term investments subdivided in:

-The securities listed on the stock exchange and valued against the market price.

-The remaining securities valued against the lower of cost or market

The notes should disclose to what extent these investments are not at the free disposal of the legal entity.

\section{Revaluation reserve fixed assets}

The notes concerning owner's equity should disclose the revaluation reserve fixed assets (article 14 Guidelines). The donations to the reserve and the cost equalization provision are charged against the profit and loss account. Buildings are carried at cost less accumulated depreciation.

\section{Provisions}

The provision for maintenance is shown separately. In the notes the provisions for student relief-fund and the half pay after dismissal are disclosed separately, too. 


\section{Cash accounting}

Cash accounting for holiday allowance, for the benefits for sick pay and for lecture fees is allowed (article 17 Guidelines). In the notes a cash flow statement is included and the average number of people employed broken down in function/category and principal cost center is disclosed (article 22 Guidelines).

\section{Budget}

The budget amounts concerning the statement of cost and revenues are disclosed (article 26-31 Guidelines).

\section{Format}

Article 24 of the Guidelines prescribes several balance sheet and statement of cost and revenues formats for filing purposes.

\section{Revenues from third parties}

The revenues from third parties are itemized by means of the nature of the activity and the type of principal.

\subsection{New reporting rule (2000)}

Some features of the new reporting rules:

A cash flow statement based on the indirect method is prescribed, classified into cash flows from operating, financing and investment activities (article 27)

- Valuation at current cost is not permitted for universities. (Article 28-1)

- Work in progress is valued based on the completed contract method (article 28-9)

- $\quad$ Depreciation terms are prescribed: buildings before 200030 years, plants 15 years (article 29-6)

- $\quad$ Research and Development costs are expended as incurred (article 11)

- Investments are carried at cost or lower market price and if the actual value on the balance sheet differs significantly from the last known market price prior to the balance sheet date the difference should be mentioned in notes (article 28-2)

- $\quad$ The report-form annual accounts (enkelvoudige jaarrekening) form parts of the notes on the consolidated accounts, in contrary to the Civil Code (article 7)

- Consolidated accounts are mandatory in the case of decisive power of the university over an entity (article 7-3) The Civil Code uses the head of the group criterion

- $\quad$ The actual OZB (real estate tax) value and the calamity insurance value of buildings and land must be disclosed (article 12-3)

- $\quad$ Books and similar are not capitalized on the balance sheet (article 12-4), the yearly cost prices are disclosed

- $\quad$ As a minimum, provisions for maintenance and half-pay (wachtgelden) are prescribed, a reconciliation statement of all the provisions is disclosed (article 21) 
The paragraphs of the Director's report (article 34) included (as a minimum):

-Characteristics of the university

-Students (binding study advice, study programs)

-Employees

-Efficiency

-Quality maintenance

-Education

-Research

-Internationalizing

-Teaching hospitals

-Accommodation

-Environment care

-Finance

\section{Earlier Research}

Hindi \& Miller (2000) examined the assessment programs used by various accounting departments across the United States. Primary skills measured in assessment included professional knowledge, problem solving, and communication skills. A variety of assessment instruments were used including exit surveys for graduating seniors, student evaluations and alumni surveys. There was a statistically significant relationship between the highest degree awarded by the institution and the use of assessment. The higher the degree awarded, the greater the number of responses that identified meeting responsibility to students and to the public as primary uses of assessment data.

Groves, Pendlebury and Stiles (1997) investigated the application of strategic thinking and models into the British education scene. The cozy and comfortable world of the ivory tower image of a university is probably gone forever and universities have to learn to exist in a world where completion affects all of their activities. Strategic management techniques can make a substantial contribution to university management, but universities do not appear to conform readily to the corporate model of strategy making, because the nature of their processes and products (teaching, research and support services) is very different. Yet, an awareness of competitive position, advantage and scope and the value chain of a university can be useful tools for some prioritization between research selectivity, teaching excellence and income generation.

Broadbent, Laughlin, Willig-Atherton (1994) consider the nature of accounting in schools: Local Management of Schools (LMS). Accounting cannot be a decision instrument for the schools, but is very important as a communication tool: accounting information is being used as one element to justify and legitimate decisions; they are being used to convince others, as a tool of rhetoric, to play the budget game. Accounting information is used in a tactical way to communicate particular realities. 
Pendlebury \& Algaber (1997) stated that universities have traditionally relied on a top-slicing arrangement for recovering central support costs, rather than attempting to allocate these costs to academic departments benefiting from the central support. The results of their survey reveal that close to $50 \%$ of universities still rely on top-slicing, in other parts of the public sector, cost allocations are being increasingly replaced by service level agreements, internal market prices and market testing through competitive tendering. Allocation turns out to be too complex. However, the nature of much of the central support services in universities is not distinctly different from those in central and local government and therefore similar developments might be expected in the future.

The Commission Koopmans (1999) investigated the financial position of the universities. They concluded that the equity capital has a buffer function with a desired size of $10 \%$ of the government contribution revenues.

The Commission calculated the equity capital of all the universities together end 1997 on 3,557 million of guilders after writing down the buildings/land with 361 millions, equipment/books with 263 millions and increasing the half-pay provisions with 752 millions of guilders. Based on some assumptions all universities together have a capital deficit of 1.6 milliard of guilders.

Recommendations of the Commission Koopmans:

-The use of accrual accounting

-No distinction between general and special reserves

-Investments has carried on as current assets valued at market values

-No provisions for maintenance, but capitalizing of the outlays

Linking with his 1992 dissertation concerning the application of fund accounting to the municipal financial report, Volmer (1999) investigated the power of fund accounting to improve the financial control of the government. The agency model turned out to be such an application. Universities use specific funds carried on as provisions on the balance sheet for a long time already

Banker ca (1989) investigated school district financial reporting practices. Starting point was the financial report and the notes based on fund accounting (general fund, special revenue funds, capital projects fund, debt service fund) divided into balance sheet, statement of cost and revenues, budget. The compliance to the prescribed accounting rules was summarized in Disclosure Index. To explain the differences in financial reporting some factors are recognized: (pp 32-36)

1. Higher levels of Government;

2. Investors and Bond Analysts;

3. Auditors;

4. Coalitions

5. Professionalism;

6. Political Factors;

7. Cost of a Financial Reporting System;

8. State Financial Reporting Requirements.

The measurement was based on some proxy variables: 
1. Government grants as a \% of total revenues

2. The size of the long-term debts

3. The use of a public auditor

4. The number enlisted students

5. See 3

6. Private or public university

7. The revenues per student

8. Prescribed reporting rules by a State

Results: variables 2, 3 and 8 are significant.

Chase \& Coffman (1994) tried to explain the accounting choice between cost and market value of the investments on the balance sheet of 330 higher education institutes.

From three explaining factors derived from earlier research, the size of the investments, the management compensation agreements and the relative size of the debt, only the first two factors turned out to be significant.

\section{Empirical research: Descriptive statistics (1998)}

Table 1 shows the key data such as the number of students, total revenues and the cost of a graduate.

The university of Utrecht has most students, followed closely by the university of Amsterdam (both about 21.600 students), after this the university of Groningen follows with about 4.000 students less. The same holds for the revenues (the university of Utrecht has more than 1 billion of guilders revenues). Based on costs the university order is Amsterdam, Groningen, Utrecht.

The university of Amstedam has most graduates, followed by Groningen and Nijmegen.

Cost of a graduate varies from 568.000 guilders (Wageningen university) to 153.000 guilders (Tilburg university). The average cost of a graduate is 364.000 guilders. Declining interest in a field of study results in sharp increasing costs per student.

The private universities VU Amsterdam and Catholic University Nijmegen belong to the middle class based on the number of students (12.000 to 13.000), the university of Brabant is smaller (about 7.500 students). The average in the Netherlands is 12.250 students, 1.540 graduates, and 360.000 guilders costs per graduate. However, the standard deviation is high (about 50\%),

Table 2 shows some key data.

Utrecht University has most equity capital (about 800 million guilders) followed by the universities of Delft and Amsterdam. It strikes that four universities run into 
long- term debts. Erasmus University Rotterdam (57 billion of guilders), Polytechnic University Eindhoven (12 million guilders), Polytechnic University Twente and Utrecht University (3 to 4 millions of guilders'). The universities of Brabant and Delft have deficits. Most universities have exceptional income and expenses; those of the universities of Brabant, Wageningen and Eindhoven were unfavorable.

The size of the university financial report varies from 46 pages (Amsterdam University) to 149 pages (Erasmus University Rotterdam). The average amounts to 86 pages, the standard deviation is rather high (30 pages). The size of the financial report in a narrower sense is less by half ( 8.7 pages). Most universities provide information by consolidated statements with exception of the private universities, the Wageningen University and the Open University. Nearly all Universities showed (1998) reports of approval; Amsterdam University showed a report with reservation and Leiden University a statement of denial of opinion.

\section{Hypothesis}

Based on the research mentioned above, the following hypotheses are developed:

(I) The more long term debt, the larger the size of the financial report (1), the annual accounts (2), the key data (3), the analysis of income (4) and the income from exploitation (5)

Based on the Debt/Equity hypothesis of Watt's \& Zimmerman (1986)

"Ceterus paribus, the larger a firm's debt/equity ratio, the more likely the firm's manager is to select accounting procedures that shift reported earnings from future periods to current period" (pp. 216). ). In de non-profit sector, earnings shift is replaced by more information about several qualitative objections, because performance and not profit is crucial here.

(II) The higher total revenues and the lower the income, the more changes in accounting principles in the annual accounts.

See Watt's \& Zimmerman again.

(III) The higher the investments, the investment income and the financing by long term debt, the more market values for investments in the balance sheet shall be used.

See earlier research: Chase and Coffman (1994)

Results

The first hypothesis is correct with exception of the variable exploitation income: 
Total Report

Adj Rsquare coeff $\mathrm{t}$

P $\quad \mathrm{F}$

Annual Accounts

0.31

1.2

2.6

0.02

6.9

Key Data

0.21

0.59

2.1

0.06

4.4

Analyze Income

0.62

0.07

4.8

0.00

22.4

Exploitation Income

0.70

0.13

5.6

0.00

31.3

$-0.07$

$-0.14 \quad-0.4$

0.72

0.14

The second hypothesis is correct

$\begin{array}{lcccll} & \text { Adj Rsquare } & \text { coeff } & \mathrm{t} & \mathrm{P} & \mathrm{F} \\ \text { Exploitation income } & 0.34 & -0.001 & -2.36 & 0.04 & 4.41 \\ \text { Total revenues } & 0.34 & 0.0015 & 2.85 & 0.02 & 4.41\end{array}$

The third hypothesis is incorrect with exception of the variable investment income

$\begin{array}{cccccc} & \text { Adj Rsquare } & \text { coeff } & \mathrm{t} & \mathrm{P} & \mathrm{F} \\ \text { Investment size } & 0.23 & 0.17 & 2.2 & 0.049 & 4.8\end{array}$

\section{Disclosure Research}

How to measure the qualities of financial reports of universities and which factors determine the level?

To answer the first question, a disclosure model will be developed consisting of the next variables (based on earlier research):

-The size of the financial report

-The practice of consolidation

-The structure of the cash flow statement

-The balance sheet notes

-The accounting principles

-The number of provisions/reserves

-The details of the statement of costs and revenues

-The information the output

See tables 1-8 to summarize this information in a single disclosure index, the scores of each of the elements are determined. See Table 9. As a rule the existence of an element determines the score (one point); the important element consolidation 9 points. However, a scale is used for determining the scores of some special elements: 
Size of the report

$\begin{array}{ll}<31 \text { pages } & 0 \\ \text { 31-60 pages } & 1 \\ 61-90 \text { pages } & 2 \\ 91-120 \text { pages } & 3 \\ >120 \text { pages } & 4\end{array}$

Number of provisions

0-4 provisions $\quad 0$

5-7 provisions 1

8-11 provisions 2

$>11$ provisions 3

Splitting up categories

Number of reserves

Work for third parties

0-4 elements $\quad 0$

0-2 reserves $\quad 0$

5-8 elements $\quad 1$

3-4 reserves $\quad 1$

9-12 elements 20 5-6 reserves 2

$>12$ elements $\quad 3-8$ reserves 3

$>8$ reserves 4

This measurement procedure is subjective indeed, but it makes comparison possible. See Table 9. The final score differs from 2.8 to 7.8 on a ten scale.

The proxy variables used by Banker ca (1989) in his research are adopted to explain the all-in Disclosure Index, with exception of Banker's variable 8 (State Regulations), because in the Netherlands only central level regulation exists in contrast to a federal state. So the used variables are:

1) Governmental subsidies in a \% of total university revenues

2) The size of the long debts

3) The use of public auditors

4) The number of enlisted students

5) Private or public university

6) Revenues per student

Results

The number of enlisted students (var. 4), the kind of university (var. 5) and the revenues per student (var. 6) turned out to be significant: adj $\mathrm{R}$ square $=0.30 \mathrm{P}=0.09$ See Table beneath 
Independent variables

(4) Number of students (x1000)

(5) Kind university (1=private; $2=$ public)

(6) Revenues per student (x1000)

Constant

$$
\text { coeff }
$$

$-0.15$

1.75

$-0.04$

6.6
$\mathrm{P}$

0.03

0.04

0.08

The impact of the number of students and revenues per student are negative. The kind of university has a positive influence. The other variables are not significant.

The correlatiematrix shows the multicollinarity between the variables

$\begin{array}{lrccc} & \text { constant } & \text { var. (4) } & \text { var. (6) } & \text { var. (5) } \\ \text { constante } & 1 & & & \\ \text { Var. (4) } & -0.56 & 1 & & \\ \text { var. (6) } & -0.58 & 0.61 & 1 & \\ \text { var. (5) } & -0.37 & -0.39 & -0.44 & 1\end{array}$

In Table 11 explaining factors concerning parts of the financial report (S1-S8) are showed. The results are in short:

1. The size of the financial report and the use of internal auditors are correlated.

2. Public universities use more consolidated accountant than private universities.

3. The more universities depend on subsidies, the smaller the cash flow statements

4. The more exceptional income and the less the dependence of subsidies, the more extensive notes and analysis on the financial report.

5. The more university staff and higher deficits, the more advanced accounting principles (such as actual values and capitalizing of books)

6. Private universities and universities with external auditors has more provisions and reserves.

7. The more revenues per student the more extensive cost and revenues statements

8. The more enlisted students, the less information disclosures about performance (output).

Chase \& Coffman investigated 330 higher education organizations to explain the relation between market values in the balance sheets and the size of the investments, the level of the investment performance, the long-term debt/ worth investments.

Only the first two factors turned out to be significant on 5\% level.

In our research only the investment performance was significant on $7 \%$ level. However, only three universities (the poly techniques) used market values for investments on the balance sheet.

\section{Limitations of the research}


The results are limited by some important facts. The number of universities in the Netherlands is 14 only (Nijenrode University excepted) and only the year 1998 was investigated. Besides that, the financial report of a university is as a matter of fact not the only medium for communication. Or responsibility accounting. Several other ways do exist such as the scientific report and other university publications. More research over more years is indicated.

\section{Conclusions}

This paper describes research done concerning the size, level and explanation of the financial reports (1998) of 14 Dutch universities.

Based on earlier research in the USA concerning the financial report of universities, 14 Dutch financial reports are examined. See the Tables.

In spite of the regulations, the quantity and quality of the financial university reports diverge much, in particular the information provided about costs and output of education and research varies from university to university.

For an explanation of the data a number well-known hypotheses such as Zimmerman's size, debt/equity hypothesis were tested first. After that a disclosure index was developed for expressing the several information items in a unique report mark per university.

The results can be explained by the kind of university, the size (number of students and revenues) and the long-term liabilities, in accordance with the research abroad. Therefore the main conclusion is that the findings of the research outside the Netherlands such as the importance of size and long-term liabilities hold largely in the Netherlands, too.

References

Banker, R.D., Bunch B.S., Strauss, R.P. Factors Influencing School District Financial Reporting Practices, Research in Governmental and Nonprofit Accounting, vol.5, pp 27-56,1989

Broadbent, J., Laughlin, R., Willig-Atherton, H. 
Financial Controls and Schools: Accounting in " Public" and "Private" Spheres, British Accounting Review (1994) 26, 255-279.

Groves, R.E.V., Pendlebury, Stiles, D.R.,

A Critical Appreciation of the Uses for Strategic Management Thinking, Systems and Techniques in British Universities, Financial Accountability \& Management, 13 (4), November 1997.

Graan, G.B.K., Volmer F.G. (red)

Performance Budgeting. A perspective on Modeling and Strategic Planning in the Public Sector in Holland, 1998

Hind, N., Miller, D.,

A Survey of Assessment Practices in Accounting Departments of Colleges and Universities, Journal of Education for Business, May/June 2000.

Commissie Koopmans De Vermogenspositie van de Universiteiten.

Een delicate balans, juli 1999

Pendlebury, M., Algaber, N.,

Accounting for the Cost of Central Support Services in UK Universities. A Note, Financial Accountability \& Management, 13

(3), August 1997.

Volmer, F.G. $\quad$ Enige beschouwingen met betrekking tot de Gemeenterekening, Rotterdam 1992

Volmer, F.G. $\quad$ Fund Accounting en Agentschappen, De Accountant, Oktober 1999/2

Watts, R., Zimmerman, J.L. Positive Accounting Theory, 1986.

Witkam, H.J.

De Financiën van de Leidse Universiteit in de $16 e$ eeuw, 1980 . 
Table 1: key data universities 1998

\begin{tabular}{||l|c|c|c|c|c||}
\hline Universities & $\begin{array}{l}\text { number } \\
\text { of stu- } \\
\text { dents }\end{array}$ & $\begin{array}{l}\text { Total } \\
\text { revenue } \\
\text { mln gld }\end{array}$ & $\begin{array}{l}\text { Total } \\
\text { cost } \\
\text { mln gld }\end{array}$ & $\begin{array}{l}\text { number } \\
\text { of gra- } \\
\text { duates }\end{array}$ & $\begin{array}{l}\text { cost/ } \\
\text { graduate }\end{array}$ \\
\hline Utrecht & 21.635 & 1.037 & 997 & 3.124 & 319 \\
\hline Amsterdam & 21.612 & 872 & 853 & 3.196 & 267 \\
\hline Groningen & 17.366 & 782 & 757 & 2.420 & 312 \\
\hline Erasmus & 13.910 & 533 & 524 & 1.861 & 281 \\
\hline Leiden & 13.781 & 692 & 686 & 1.819 & 377 \\
\hline vU A'dam & 13.370 & 643 & 593 & 1.665 & 356 \\
\hline TU Delft & 13.002 & 779 & 794 & 1.615 & 492 \\
\hline Nijmegen & 12.319 & 689 & 672 & 2.144 & 313 \\
\hline Maastricht & 10.039 & 408 & 406 & 1.263 & 321 \\
\hline KU Brabant & 7.519 & 186 & 186 & 1.215 & 153 \\
\hline TU Twente & 5.648 & 362 & 355 & 816 & 435 \\
\hline TU Eindhoven & 5.209 & 391 & 374 & 773 & 483 \\
\hline Wageningen & 3.830 & 387 & 372 & 655 & 568 \\
\hline Open Univ. & 21.856 & 100 & 102 & 286 & 355 \\
\hline Total & 159.240 & 7.861 & 7.360 & 21.547 & 5.090 \\
\hline Average & 12.249 & 562 & 526 & 1.539 & 364 \\
\hline $\begin{array}{l}\text { Standard } \\
\text { deviation }\end{array}$ & 5.548 & 259 & 223 & 747 & 102 \\
\hline & & & & & \\
\hline
\end{tabular}

Table 2 Financial Key information universities 1998

\begin{tabular}{||l|c|c|c|c|c||}
\hline $\begin{array}{l}\text { Universi- } \\
\text { ties } \\
\text { year: 1998 }\end{array}$ & $\begin{array}{l}\text { equity } \\
\text { capital } \\
\text { mln gld }\end{array}$ & $\begin{array}{l}\text { lg term } \\
\text { debts } \\
\text { mln gld }\end{array}$ & $\begin{array}{l}\text { person- } \\
\text { al cost } \\
\text { mlngld } \\
\text { (fte's) }\end{array}$ & $\begin{array}{l}\text { exploit } \\
\text { result } \\
\text { mln gld }\end{array}$ & $\begin{array}{l}\text { except. } \\
\text { income } \\
\text { mln gld }\end{array}$ \\
\hline Utrecht & 799 & 3 & 611 & 40 & 0
\end{tabular}




\begin{tabular}{|c|c|c|c|c|c|}
\hline & & & $(5667)$ & & \\
\hline Amsterdam & 469 & 0 & $\begin{array}{c}472 \\
(3861)\end{array}$ & 21 & 2 \\
\hline Groningen & 639 & 0 & $\begin{array}{c}427 \\
(3292)\end{array}$ & 25 & 0 \\
\hline Erasmus & 483 & 57 & $\begin{array}{l}278 \\
(2612) \\
\end{array}$ & 9 & 0 \\
\hline Leiden & 266 & 0 & $\begin{array}{c}367 \\
(1979)\end{array}$ & 61 & 55 \\
\hline vU A'dam & 454 & 3 & $\begin{array}{c}344 \\
(3345) \\
\end{array}$ & 49 & 0 \\
\hline TU Delft & 444 & 0 & $\begin{array}{c}563 \\
(4490) \\
\end{array}$ & -2 & 13 \\
\hline Nijmegen & 444 & 0 & $\begin{array}{c}376 \\
(3812) \\
\end{array}$ & 18 & 1 \\
\hline Maastricht & 334 & 0 & $\begin{array}{l}207 \\
(2016)\end{array}$ & 3 & 0 \\
\hline KU Brabant & 183 & 0 & $\begin{array}{l}135 \\
(1155)\end{array}$ & -6 & -10 \\
\hline TU Twente & 300 & 4 & $\begin{array}{l}228 \\
(2197) \\
\end{array}$ & 7 & 0 \\
\hline $\begin{array}{l}\text { TU Eindh- } \\
\text { oven }\end{array}$ & 336 & 12 & $\begin{array}{c}231 \\
(2397) \\
\end{array}$ & 13 & -4 \\
\hline Wageningen & 264 & 0 & $\begin{array}{l}235 \\
(2358) \\
\end{array}$ & 6 & -9 \\
\hline $\begin{array}{l}\text { Open Uni- } \\
\text { versity }\end{array}$ & 69 & 0 & $\begin{array}{l}63 \\
(559) \\
\end{array}$ & 1 & 3 \\
\hline Total & 5484 & 79 & 4537 & 245 & 51 \\
\hline Average & 392 & 5.6 & $\begin{array}{l}2839 \\
(324) \\
\end{array}$ & 17.5 & 3.6 \\
\hline $\begin{array}{l}\text { Standard } \\
\text { deviation }\end{array}$ & 185 & 15.1 & $\begin{array}{l}1345 \\
(157.5)\end{array}$ & 20 & 15.7 \\
\hline
\end{tabular}

Table 3: Financial Report universities 1998

\begin{tabular}{|c|c|c|c|c|c|c|}
\hline $\begin{array}{l}\text { Universi- } \\
\text { ty } \\
\text { year: } 1998\end{array}$ & $\begin{array}{l}\text { fin. } \\
\text { report } \\
\text { pp }()= \\
\text { score } 1\end{array}$ & $\begin{array}{l}\text { annual } \\
\text { account } \\
\text { s pp. } \\
\text { (tappen } \\
\text { dices) }\end{array}$ & $\begin{array}{l}\text { consoli } \\
\text { dation } \\
()= \\
\text { score } 2\end{array}$ & $\begin{array}{l}\text { opinion } \\
\text { auditor }\end{array}$ & $\begin{array}{l}\text { auditor } \\
\text { firm }\end{array}$ & $\begin{array}{l}\text { parts } \\
\text { cash } \\
\text { flow } \\
\text { statem } \\
\text { (score3) }\end{array}$ \\
\hline Utrecht & $\begin{array}{l}90 \\
(2)\end{array}$ & 27 & $\begin{array}{l}\text { yes } \\
(9)\end{array}$ & $\begin{array}{l}\text { appro- } \\
\text { val }\end{array}$ & KPMG & 3 \\
\hline Amsterdam & $\begin{array}{l}46 \\
(1)\end{array}$ & 34 & $\begin{array}{l}\text { yes } \\
(9)\end{array}$ & $\begin{array}{l}\text { reser } \\
\text { vation }\end{array}$ & KPMG & 2 \\
\hline Groningen & $\begin{array}{l}68 \\
(2)\end{array}$ & 41 & $\begin{array}{l}\text { yes } \\
(9)\end{array}$ & $\begin{array}{l}\text { appro- } \\
\text { val }\end{array}$ & $\begin{array}{l}\text { Price } \\
\text { Waterh }\end{array}$ & 3 \\
\hline
\end{tabular}




\begin{tabular}{|c|c|c|c|c|c|c|}
\hline Erasmus & $\begin{array}{l}149 \\
(4)\end{array}$ & $\begin{array}{c}52 \\
(79) \\
\end{array}$ & $\begin{array}{l}\text { yes } \\
(9)\end{array}$ & $\begin{array}{l}\text { appro- } \\
\text { val }\end{array}$ & intern & 3 \\
\hline Leiden & $\begin{array}{l}95 \\
(3) \\
\end{array}$ & $\begin{array}{c}31 \\
(58) \\
\end{array}$ & $\begin{array}{l}\text { yes } \\
(9)\end{array}$ & $\begin{array}{l}\text { denial } \\
\text { of opin }\end{array}$ & intern & 3 \\
\hline VU A'dam & $\begin{array}{l}120 \\
(3)\end{array}$ & $\begin{array}{c}21 \\
(30) \\
\end{array}$ & $\begin{array}{l}\text { no } \\
(0)\end{array}$ & $\begin{array}{l}\text { appro- } \\
\text { val }\end{array}$ & intern & 2 \\
\hline TU Delft & $\begin{array}{l}60 \\
(1)\end{array}$ & $\begin{array}{c}32 \\
(60)\end{array}$ & $\begin{array}{l}\text { yes } \\
(9)\end{array}$ & $\begin{array}{l}\text { appro- } \\
\text { val }\end{array}$ & KPMG & 2 \\
\hline Nijmegen & $\begin{array}{l}57 \\
(1) \\
\end{array}$ & $\begin{array}{c}36 \\
(57) \\
\end{array}$ & $\begin{array}{l}\text { no } \\
(0)\end{array}$ & $\begin{array}{l}\text { appro- } \\
\text { val }\end{array}$ & $\begin{array}{l}\text { Ernst } \\
\text { Young }\end{array}$ & 3 \\
\hline Maastricht & $\begin{array}{l}80 \\
(2) \\
\end{array}$ & 27 & $\begin{array}{l}\text { yes } \\
(9)\end{array}$ & $\begin{array}{l}\text { appro- } \\
\text { val }\end{array}$ & KPMG & 3 \\
\hline $\mathrm{KU}$ Brabant & $\begin{array}{l}136 \\
(4) \\
\end{array}$ & $\begin{array}{c}34 \\
(56) \\
\end{array}$ & $\begin{array}{l}\text { no } \\
(0)\end{array}$ & $\begin{array}{l}\text { appro- } \\
\text { val }\end{array}$ & $\begin{array}{l}\text { Price } \\
\text { Waterh }\end{array}$ & 3 \\
\hline TU Twente & $\begin{array}{l}70 \\
(2)\end{array}$ & 30 & $\begin{array}{l}\text { yes } \\
(9)\end{array}$ & $\begin{array}{l}\text { appro- } \\
\text { val }\end{array}$ & $\begin{array}{l}\text { Ernst } \\
\text { Young }\end{array}$ & 3 \\
\hline $\begin{array}{l}\text { TU Eindh- } \\
\text { oven }\end{array}$ & $\begin{array}{r}82 \\
(2) \\
\end{array}$ & 21 & $\begin{array}{c}j a \\
(9)\end{array}$ & $\begin{array}{l}\text { appro- } \\
\text { val }\end{array}$ & $\begin{array}{l}\text { Ernst } \\
\text { Young }\end{array}$ & 1 \\
\hline Wageningen & $\begin{array}{l}84 \\
(2) \\
\end{array}$ & $\begin{array}{c}18 \\
(35)\end{array}$ & $\begin{array}{l}\text { neen } \\
(0)\end{array}$ & $\begin{array}{l}\text { appro- } \\
\text { val }\end{array}$ & $\begin{array}{l}\text { Ernst } \\
\text { Young }\end{array}$ & 3 \\
\hline $\begin{array}{l}\text { Open Uni- } \\
\text { versity }\end{array}$ & $\begin{array}{r}72 \\
(2) \\
\end{array}$ & 29 & $\begin{array}{l}\text { neen } \\
(0)\end{array}$ & $\begin{array}{l}\text { appro- } \\
\text { val }\end{array}$ & $\begin{array}{l}\text { Ernst } \\
\text { Young }\end{array}$ & 2 \\
\hline Total & 1209 & 433 & 81 & $12+$ & 3 int & 36 \\
\hline Average & 86 & 31 & $(5.8)$ & $1 ?$ & $12 \mathrm{ext}$ & 2.6 \\
\hline Stand.dev & 30 & 8.7 & & $1-$ & & 0.6 \\
\hline
\end{tabular}

Table 4: Notes with relation to the Balance sheet

\begin{tabular}{|c|c|c|c|c|c|c|}
\hline $\begin{array}{l}\text { University } \\
\text { year: } \\
1998\end{array}$ & $\begin{array}{l}\text { key } \\
\text { data }\end{array}$ & $\begin{array}{l}\text { info } \\
\text { about } \\
\text { future }\end{array}$ & budget & $\begin{array}{l}\text { multi } \\
\text { years } \\
\text { analysi } \\
\text { s }\end{array}$ & $\begin{array}{l}\text { analy- } \\
\text { sis } \\
\text { perform } \\
\text { ance }\end{array}$ & $\begin{array}{l}\text { total } \\
\text { score } 4\end{array}$ \\
\hline Utrecht & 0 & 0 & 1 & 0 & 1 & 2 \\
\hline Amsterdam & 1 & 1 & 0 & 1 & 1 & 4 \\
\hline Groningen & 1 & 0 & 0 & 1 & 1 & 3 \\
\hline Erasmus & 1 & 0 & 1 & 1 & 1 & 4 \\
\hline Leiden & 1 & 1 & 1 & 1 & 1 & 5 \\
\hline VU A'dam & 1 & 0 & 0 & 1 & 1 & 3 \\
\hline
\end{tabular}




\begin{tabular}{|c|c|c|c|c|c|c|}
\hline TU Delft & 0 & 0 & 1 & 0 & 0 & 1 \\
\hline Nijmegen & 1 & 0 & 0 & 0 & 1 & 2 \\
\hline Maastricht & 1 & 0 & 0 & 1 & 1 & 3 \\
\hline $\mathrm{KU}$ Brabant & 1 & 1 & 0 & 1 & 1 & 4 \\
\hline TU Twente & 1 & 1 & 0 & 1 & 1 & 4 \\
\hline $\begin{array}{l}\text { TU Eind- } \\
\text { hoven }\end{array}$ & 1 & 0 & 0 & 1 & 1 & 3 \\
\hline Wageningen & 1 & 1 & 0 & 1 & 1 & 4 \\
\hline $\begin{array}{l}\text { Open Uni- } \\
\text { versity }\end{array}$ & 0 & 0 & 1 & 0 & 1 & 2 \\
\hline Total & 11 & 5 & 5 & 10 & 13 & 44 \\
\hline Average & $79 \%$ & $46 \%$ & $46 \%$ & $72 \%$ & $93 \%$ & 3.1 \\
\hline
\end{tabular}

Table 5: Accounting (valuation) principles

\begin{tabular}{|c|c|c|c|c|c|c|c|c|}
\hline $\begin{array}{l}\text { University: } \\
\text { year } \\
1998\end{array}$ & $\begin{array}{l}\text { ex- } \\
\text { plai- } \\
\text { ning } \\
\text { princ } \\
\text { iples }\end{array}$ & $\begin{array}{l}\text { explai } \\
\text { ing ac } \\
\text { count- } \\
\text { ing } \\
\text { change }\end{array}$ & $\begin{array}{l}\text { notes } \\
\text { intan } \\
\text { gible } \\
\mathbf{s}\end{array}$ & $\begin{array}{l}\text { notes } \\
\text { actual } \\
\text { values }\end{array}$ & $\begin{array}{l}\text { depre } \\
\text { ciate } \\
\text { build } \\
\text {-ing } \\
30 \\
\text { years } \\
\end{array}$ & $\begin{array}{l}\text { books } \\
\text { on ba } \\
\text { lance } \\
\text { sheet }\end{array}$ & $\begin{array}{l}\text { depre } \\
\text { ciati } \\
\text { on on } \\
\text { books }\end{array}$ & $\begin{array}{c}\text { score } \\
\text { (5) }\end{array}$ \\
\hline Utrecht & 0 & 1 & 1 & 1 & 1 & 0 & 0 & 4 \\
\hline Amsterdam & 1 & 1 & 0 & 0 & 1 & 0 & 0 & 3 \\
\hline Groningen & 1 & 0 & 0 & 0 & 1 & 0 & 0 & 2 \\
\hline Erasmus & 1 & 0 & 0 & 0 & 0 & 0 & 0 & 3 \\
\hline Leiden & 1 & 0 & 0 & 0 & 1 & 0 & 0 & 2 \\
\hline VU A'dam & 1 & 0 & 0 & 1 & 0 & 0 & 0 & 2 \\
\hline TU Delft & 1 & 1 & 1 & 1 & 1 & 0 & 0 & 5 \\
\hline Nijmegen & 1 & 1 & 1 & 1 & 1 & 0 & 0 & 5 \\
\hline Maastricht & 1 & 0 & 0 & 1 & 0 & 1 & 0 & 3 \\
\hline KU Brabant & 1 & 1 & 0 & 1 & 0 & 1 & 1 & 4 \\
\hline
\end{tabular}




\begin{tabular}{||l|c|c|c|c|c|c|c|c||}
\hline TU Twente & 1 & 0 & 0 & 1 & 1 & 1 & 0 & 4 \\
\hline $\begin{array}{l}\text { TU Eind- } \\
\text { hoven }\end{array}$ & 1 & 0 & 1 & 1 & 1 & 0 & 0 & 4 \\
\hline $\begin{array}{l}\text { Wageningen } \\
\begin{array}{l}\text { Open Uni- } \\
\text { versity }\end{array}\end{array}$ & 1 & 0 & 0 & 1 & 0 & 0 & 1 & 3 \\
\hline \begin{tabular}{l} 
Total \\
\hline Average
\end{tabular} & $87 \%$ & $36 \%$ & $29 \%$ & $64 \%$ & $57 \%$ & $21 \%$ & $14 \%$ & 3.2 \\
\hline
\end{tabular}

Table 6: Contingincies (provisions) and reserves

\begin{tabular}{|c|c|c|c|c|c|}
\hline $\begin{array}{l}\text { University } \\
\text { : year } \\
1998\end{array}$ & $\begin{array}{l}\text { number } \\
\text { of } \\
\text { provisi- } \\
\text { ons } \\
\text { (score) }\end{array}$ & $\begin{array}{l}\text { mainten- } \\
\text { ance } \\
\text { provision }\end{array}$ & $\begin{array}{l}\text { provision } \\
\text { for } \\
\text { students }\end{array}$ & $\begin{array}{l}\text { number of } \\
\text { reserves } \\
\text { (score) }\end{array}$ & $\begin{array}{l}\text { total } \\
\text { score } \\
(6)\end{array}$ \\
\hline Utrecht & $2(0)$ & 1 & 0 & 4 (1) & 2 \\
\hline Amsterdam & 11 (2) & 1 & 1 & $1(0)$ & 4 \\
\hline Groningen & $4(0)$ & 1 & 1 & 4 (1) & 3 \\
\hline Erasmus & $3(0)$ & 1 & 1 & $4 \quad(1)$ & 3 \\
\hline Leiden & $4(0)$ & 0 & 1 & $2(0)$ & 1 \\
\hline VU A'dam & 8 (2) & 0 & 1 & $2(0)$ & 3 \\
\hline TU Delft & 10 (2) & 0 & 1 & 8 (3) & 6 \\
\hline Nijmegen & $16(3)$ & 1 & 1 & $9 \quad(4)$ & 9 \\
\hline Maastricht & 9 (2) & 1 & 1 & $2(0)$ & 4 \\
\hline KU Brabant & 9 (2) & 1 & 1 & 7 (3) & 7 \\
\hline TU Twente & 10 (2) & 1 & 1 & 7 (3) & 7 \\
\hline $\begin{array}{l}\text { TU Eind- } \\
\text { hoven }\end{array}$ & 5 (1) & 1 & 1 & $1(0)$ & 3 \\
\hline Wageningen & 5 (1) & 0 & 1 & 4 (1) & 3 \\
\hline
\end{tabular}




\begin{tabular}{||l|c|c|c|c|c||}
\hline $\begin{array}{l}\text { Open Uni- } \\
\text { versity }\end{array}$ & $11(2)$ & 1 & 0 & $1(0)$ & 4 \\
\hline Total & 107 & 10 & 12 & 56 & 59 \\
\hline Average & 7.6 & $71 \%$ & $86 \%$ & 4 & 4.2 \\
\hline
\end{tabular}

Table 7: Statement of cost and revenues

\begin{tabular}{|c|c|c|c|c|c|}
\hline $\begin{array}{l}\text { University } \\
\text { year: } \\
1998\end{array}$ & $\begin{array}{l}\text { muta- } \\
\text { tion } \\
\text { work in } \\
\text { progres } \\
\text { s }\end{array}$ & $\begin{array}{l}\text { income } \\
\text { invest- } \\
\text { ments }\end{array}$ & $\begin{array}{l}\text { excep- } \\
\text { tional } \\
\text { income }\end{array}$ & $\begin{array}{l}\text { info } \\
\text { about } \\
\text { work } \\
\text { third } \\
\text { parties }\end{array}$ & $\begin{array}{l}\text { total } \\
\text { score } 7\end{array}$ \\
\hline Utrecht & 0 & 0 & 0 & 3 & 3 \\
\hline Amsterdam & 1 & 0 & 1 & 2 & 4 \\
\hline Groningen & 1 & 0 & 0 & 2 & 3 \\
\hline Erasmus & 1 & 0 & 0 & 1 & 2 \\
\hline Leiden & 1 & 0 & 1 & 2 & 4 \\
\hline VU A'dam & 1 & 0 & 0 & 2 & 3 \\
\hline TU Delft & 0 & 1 & 1 & 1 & 3 \\
\hline Nijmegen & 1 & 0 & 1 & 1 & 3 \\
\hline Maastricht & 1 & 0 & 0 & 1 & 2 \\
\hline KU Brabant & 1 & 0 & 1 & 0 & 2 \\
\hline TU Twente & 1 & 0 & 1 & 2 & 4 \\
\hline $\begin{array}{l}\text { TU Eind- } \\
\text { hoven }\end{array}$ & 1 & 0 & 1 & 0 & 2 \\
\hline Wageningen & 1 & 0 & 1 & 3 & 5 \\
\hline $\begin{array}{l}\text { Open Univer- } \\
\text { sity }\end{array}$ & 0 & 1 & 1 & 0 & 2 \\
\hline Total & 11 & 2 & 9 & 20 & 42 \\
\hline Average & $79 \%$ & $18 \%$ & $64 \%$ & 1.4 & 3 \\
\hline
\end{tabular}


Table 8: Output per faculty

\begin{tabular}{|c|c|c|c|c|c|c|c|c|}
\hline $\begin{array}{l}\text { Universi- } \\
\text { ty year: } \\
1998\end{array}$ & $\begin{array}{l}\text { work } \\
\text { third } \\
\text { partie } \\
\text { s } \\
\text { per } \\
\text { fac }\end{array}$ & $\begin{array}{l}\text { cos } \\
t \\
\text { per } \\
\text { fac } \\
\text {. }\end{array}$ & $\begin{array}{l}\text { inco- } \\
\text { me/ } \\
\text { fac }\end{array}$ & $\begin{array}{l}\text { prop } \\
\text { exam } \\
\text { /fac }\end{array}$ & $\begin{array}{l}\text { doct } \\
\text { exam } \\
\text { /fac }\end{array}$ & diss & publ & $\begin{array}{c}\text { score } \\
(8)\end{array}$ \\
\hline Utrecht & 1 & 1 & 0 & 1 & 1 & 0 & 0 & 4 \\
\hline Amsterdam & 1 & 1 & 0 & 0 & 0 & 1 & 0 & 3 \\
\hline Groningen & 1 & 1 & 1 & 1 & 1 & 1 & 0 & 6 \\
\hline Erasmus & 0 & 1 & 1 & 1 & 1 & 1 & 0 & 5 \\
\hline Leiden & 1 & 1 & 1 & 1 & 1 & 1 & 1 & 7 \\
\hline VU A'dam & 0 & 1 & 0 & 1 & 1 & 1 & 1 & 5 \\
\hline TU Delft & 1 & 1 & 1 & 0 & 1 & 1 & 0 & 5 \\
\hline Nijmegen & 1 & 1 & 0 & 0 & 0 & 1 & 0 & 3 \\
\hline Maastricht & 1 & 1 & 1 & 1 & 1 & 1 & 1 & 7 \\
\hline KU Brabant & 0 & 1 & 0 & 1 & 1 & 1 & 1 & 5 \\
\hline TU Twente & 1 & 1 & 0 & 1 & 1 & 1 & 1 & 6 \\
\hline $\begin{array}{l}\text { TU Eind- } \\
\text { hoven }\end{array}$ & 0 & 0 & 0 & 1 & 1 & 1 & 1 & 4 \\
\hline Wageningen & 0 & 1 & 1 & 1 & 1 & 1 & 1 & 6 \\
\hline $\begin{array}{l}\text { Open Uni- } \\
\text { versity }\end{array}$ & 0 & 1 & 0 & 0 & 0 & 0 & 0 & 1 \\
\hline Total & 8 & 13 & 6 & 10 & 11 & 12 & 7 & 67 \\
\hline Average & $57 \%$ & $\begin{array}{l}93 \\
\frac{\circ}{0}\end{array}$ & $43 \%$ & $71 \%$ & $79 \%$ & $86 \%$ & $50 \div$ & 4.8 \\
\hline
\end{tabular}


Table 9: Recapitulation scores

\begin{tabular}{|c|c|c|c|c|c|c|c|c|c|c|}
\hline $\begin{array}{l}\text { University } \\
\text { year } 1998 \\
\text { scores } \\
\max \end{array}$ & $\begin{array}{l}\text { S } 1 \\
4\end{array}$ & $\begin{array}{r}\text { S2 } \\
9\end{array}$ & $\begin{array}{r}\text { s3 } \\
3\end{array}$ & $\begin{array}{r}54 \\
5\end{array}$ & $\begin{array}{r}\text { S5 } \\
7\end{array}$ & $\begin{array}{r}\text { S6 } \\
9\end{array}$ & S7 & $\begin{array}{r}58 \\
7\end{array}$ & $\begin{array}{ll}t & s \\
0 & c \\
t & 0 \\
& r \\
50 & e\end{array}$ & $\begin{array}{l}\operatorname{mar} \\
\mathbf{k} \\
1- \\
10\end{array}$ \\
\hline Utrecht & 2 & 9 & 3 & 2 & 4 & 2 & 3 & 4 & 29 & 5,8 \\
\hline Amsterdam & 1 & 9 & 2 & 4 & 3 & 4 & 4 & 3 & 30 & 6,0 \\
\hline Groningen & 2 & 9 & 3 & 3 & 2 & 3 & 3 & 6 & 31 & 6,2 \\
\hline Erasmus & 4 & 9 & 3 & 4 & 3 & 3 & 2 & 5 & 33 & 6,6 \\
\hline Leiden & 3 & 9 & 3 & 5 & 2 & 1 & 4 & 7 & 34 & 6,8 \\
\hline VU A'dam & 3 & 0 & 2 & 3 & 2 & 3 & 3 & 5 & 21 & 4,2 \\
\hline TU Delft & 1 & 9 & 2 & 1 & 5 & 6 & 3 & 5 & 32 & 6,4 \\
\hline Nijmegen & 1 & 0 & 3 & 2 & 5 & 9 & 3 & 3 & 26 & 5,2 \\
\hline Maastricht & 2 & 9 & 3 & 3 & 3 & 4 & 2 & 7 & 33 & 6,6 \\
\hline KU Brabant & 4 & 0 & 3 & 4 & 4 & 7 & 2 & 5 & 29 & 5,8 \\
\hline TU Twente & 2 & 9 & 3 & 4 & 4 & 7 & 4 & 6 & 39 & 7,8 \\
\hline $\begin{array}{l}\text { TU Eind- } \\
\text { hoven }\end{array}$ & 2 & 9 & 1 & 3 & 4 & 3 & 2 & 4 & 28 & 5,6 \\
\hline Wageningen & 2 & 0 & 3 & 4 & 3 & 3 & 5 & 6 & 26 & 5,2 \\
\hline $\begin{array}{l}\text { Open Uni- } \\
\text { versity }\end{array}$ & 2 & 0 & 2 & 2 & 1 & 4 & 2 & 1 & 14 & 2,8 \\
\hline Total & 31 & 81 & 36 & 44 & 45 & 59 & 42 & 67 & 405 & 81 \\
\hline Average & 2.2 & 5.8 & 2.6 & 3.1 & 3.2 & 4.2 & 3 & 4.8 & 29 & 5.8 \\
\hline Stand.dev & 1.0 & 4.5 & 0.6 & 1.1 & 1.2 & 2.2 & $\begin{array}{l}1 . \\
0\end{array}$ & 1.7 & 6.1 & 1.2 \\
\hline
\end{tabular}

Table 10: explaining variabeles in the disclosure model

\begin{tabular}{||l|l|l|l|l|l|l|l||}
\hline $\begin{array}{l}\text { University } \\
\text { year: }\end{array}$ & $\begin{array}{l}\text { number } \\
\text { of stu- } \\
\text { dents }\end{array}$ & $\begin{array}{l}\text { revenu- } \\
\text { es per } \\
\text { student }\end{array}$ & $\begin{array}{l}\text { inco- } \\
\text { me } \\
\text { from } \\
\text { expl }\end{array}$ & $\begin{array}{l}\text { sub- } \\
\text { sidy }\end{array}$ & $\begin{array}{l}\text { long } \\
\text { term } \\
\text { debt/ } \\
\text { asset } \\
\text { s }\end{array}$ & $\begin{array}{l}\text { tor } \\
\text { toudi- }\end{array}$ & $\begin{array}{l}\text { lic(2) } \\
\text { publ- } \\
\text { univ. }\end{array}$ \\
\hline
\end{tabular}




\begin{tabular}{|c|c|c|c|c|c|c|c|}
\hline Utrecht & 21635 & 47932 & 40 & 72.8 & 0.2 & 1 & 2 \\
\hline Amsterdam & 21612 & 40348 & 21 & 70.8 & 0 & 1 & 2 \\
\hline Groningen & 17366 & 45031 & 25 & 70.9 & 0 & 1 & 2 \\
\hline Erasmus & 13910 & 38318 & 9 & 66.7 & 7.5 & 0 & 2 \\
\hline Leiden & 13781 & 50214 & 61 & 72.5 & 0 & 0 & 2 \\
\hline vU A'dam & 13370 & 48093 & 49 & 70.1 & 0.5 & 0 & 1 \\
\hline TU Delft & 13002 & 59914 & -2 & 74.7 & 0 & 1 & 2 \\
\hline Nijmegen & 12319 & 55930 & 18 & 66.7 & 0 & 1 & 1 \\
\hline Maastricht & 10039 & 40641 & 3 & 68.6 & 0 & 1 & 2 \\
\hline KU Brabant & 7519 & 24737 & -6 & 64.6 & 0.2 & 1 & 1 \\
\hline TU Twente & 5648 & 64093 & 7 & 67.7 & 2.1 & 1 & 2 \\
\hline $\begin{array}{l}\text { TU Eind- } \\
\text { hoven }\end{array}$ & 5209 & 75062 & 13 & 75.8 & 2.3 & 1 & 2 \\
\hline Wageningen & 3840 & 100781 & 6 & 66 & 0 & 1 & 2 \\
\hline $\begin{array}{l}\text { Open Uni- } \\
\text { versiteit }\end{array}$ & 21856 & 45754 & 1 & 73 & 0 & 1 & 2 \\
\hline Totaal & 181106 & 736848 & 245 & 981 & 13 & $11 \mathrm{E}$ & $11 \mathrm{R}$ \\
\hline Gemiddeld & 12936 & 52632 & 17.5 & 70.1 & 0.9 & $3 I$ & $3 \mathrm{~B}$ \\
\hline stand.afw & 6112 & 18497 & 20 & 3.4 & 2.0 & & \\
\hline
\end{tabular}


Table 11: Explaining variables for sections Univ. report

\begin{tabular}{|c|c|c|c|c|c|c|c|c|}
\hline & $\begin{array}{l}\text { publ } \\
\text { audi- } \\
\text { tor }\end{array}$ & $\begin{array}{l}\text { perc. } \\
\text { subsi- } \\
\text { dy }\end{array}$ & $\begin{array}{l}\text { except } \\
\text { income }\end{array}$ & $\begin{array}{l}\text { defi- } \\
\text { cit }\end{array}$ & $\begin{array}{l}\text { privat } \\
\text { e/pu- } \\
\text { blic } \\
\text { univ- } \\
\text { ers }\end{array}$ & $\begin{array}{l}\text { revenu- } \\
\text { es/ } \\
\text { student }\end{array}$ & $\begin{array}{l}\text { number } \\
\text { of stu } \\
\text { dents }\end{array}$ & $\begin{array}{l}\text { number } \\
\text { fte's }\end{array}$ \\
\hline $\begin{array}{l}\text { Size re- } \\
\text { port }\end{array}$ & $\begin{array}{l}r^{2}=0.43 \\
P=0.02\end{array}$ & & & & & & & \\
\hline $\begin{array}{l}\text { consoli- } \\
\text { dation }\end{array}$ & & & & & $\begin{array}{l}r^{2}=0.45 \\
P=0.01\end{array}$ & & & \\
\hline $\begin{array}{l}\text { cash flow } \\
\text { sections }\end{array}$ & & $\begin{array}{l}r^{2}=0.47 \\
P=0.01\end{array}$ & & & & & & \\
\hline $\begin{array}{l}\text { expl } \\
\text { notes } \\
\text { balance } \\
\text { sheet }\end{array}$ & & $\begin{array}{l}r^{2}=0.27 \\
P=0.04\end{array}$ & $\begin{array}{l}r^{2}=0.27 \\
P=0.09\end{array}$ & & & & & \\
\hline $\begin{array}{l}\text { valuation } \\
\text { principl }\end{array}$ & & & & $\begin{array}{l}r^{2}=0.43 \\
P=0.07\end{array}$ & & & & $\begin{array}{l}r^{2}=0.43 \\
P=0.06\end{array}$ \\
\hline $\begin{array}{l}\text { provisi- } \\
\text { ons/reser } \\
\text { ves }\end{array}$ & $\begin{array}{l}r^{2}=0.48 \\
P=0.02\end{array}$ & & & & $\begin{array}{l}r^{2}=0.48 \\
P=0.01\end{array}$ & & & \\
\hline $\begin{array}{l}\text { statement } \\
\text { cost/reve } \\
\text { nues }\end{array}$ & & & & & & $\begin{array}{l}r^{2}=0.27 \\
P=0.03\end{array}$ & & \\
\hline $\begin{array}{l}\text { output } \\
\text { report }\end{array}$ & & & & & & & $\begin{array}{l}r^{2}=0.21 \\
P=0.06\end{array}$ & \\
\hline & & & & & & & & \\
\hline
\end{tabular}

Table 12 Explanation valuation principles investments universities 1998 


\begin{tabular}{||l|l|c|c|c||}
\hline $\begin{array}{l}\text { Universities } \\
\text { Year: 1998 }\end{array}$ & $\begin{array}{l}\text { market } \\
\text { value }\end{array}$ & $\begin{array}{l}\text { Rate of } \\
\text { return } \\
\text { investm. }\end{array}$ & $\begin{array}{l}\text { \% Lterm } \\
\text { Debt/in- } \\
\text { vestment }\end{array}$ & $\begin{array}{l}\text { book } \\
\text { value } \\
\text { investm }\end{array}$ \\
\hline Utrecht & 0 & 5.5 & 1.1 & 282.8 \\
\hline Amsterdam & 0 & 4.1 & 0 & 199.3 \\
\hline Groningen & 0 & 5.2 & 0 & 153 \\
\hline Erasmus & 0 & 3.7 & 58.9 & 96.7 \\
\hline Leiden & 0 & 4.7 & 0 & 107.5 \\
\hline VU A'dam & 0 & 4.2 & 1.1 & 262 \\
\hline TU Delft & 1 & 3.8 & 0 & 233 \\
\hline Nijmegen & 0 & 5.2 & 0 & 270.7 \\
\hline Maastricht & 0 & 2.3 & 0 & 33.2 \\
\hline KU Brabant & 0 & 3.8 & 0 & 85.2 \\
\hline TU Twente & 1 & 6.2 & 4.0 & 101 \\
\hline TU Eindhoven & 1 & 7.9 & 12.2 & 98.2 \\
\hline Wageningen & 0 & 4.2 & 0 & 33.7 \\
\hline Open Univ. & 0 & 4.4 & 0 & 56.7 \\
\hline Total & 3 & 65 & 77.3 & 2013 \\
\hline Average & 0.4 & 4.7 & 5.5 & 144 \\
\hline $\begin{array}{l}\text { Standard } \\
\text { deviation }\end{array}$ & 0.2 & 1.3 & 65.8 & 134 \\
\hline \hline
\end{tabular}

